\title{
Enhancing the Kinship Anthropology of Scheffler with Diachronic Linguistics and Centricity
}

\author{
Patrick McConvell
}

\section{Introduction}

This chapter is an appreciation of a figure in the anthropology of kinship in general, and particularly of Aboriginal Australia: Hal Scheffler. Scheffler's brilliant work on the formalisation of types of kinship extension and his Australian Kin Classification (1978) have been less appreciated by some in the era of 'new kinship studies' but the 'renaissance of kinship' of recent years will certainly restore its currency. Two missing elements in Scheffler's work are the diachronic dimension, and the role of linguistic evidence in reconstructing paths of change: this chapter will show concretely how these elements add to a more complete kinship ethnology. Scheffler's concept of 'extension' and his application of it to Australian Aboriginal kinship remain the foundation for work in kinship change and reconstruction, and dovetail neatly with theories of semantic change via transitional polysemy applied in Australia. However, some types of semantic change in kinship terminology do not fit so easily within the framework. I argue here that these may be more tractable if we recognise variation in pragmatic usage of terms, caused by shifts in centricity (Garde 2013; Merlan 1982) as also leading to change in meaning of terms without such obvious evidence of transitional polysemy. 


\section{Extension}

\section{The Lounsbury/Scheffler approach}

In the work of Scheffler, extension describes a purely synchronic relationship between a focal kin-term meaning and its other 'extended' meanings. In the formalism developed by Floyd Lounsbury and Scheffler, rules take kin-type strings as input and reduce them to the focal kin type. These are often referred to as 'equivalence rules' or 'reduction rules'. They are similar to rewrite rules in early generative phonology and syntax. ${ }^{1}$

Relationships between two or more meanings that are distinguished as different words in some languages, but merged as one in others, are described in various different ways also. The case where the two meanings are represented by one lexical item can be called a 'syncretism', or the word with two distinct senses can be termed 'polysemous'. The notion of 'extension' adds a further element to this by stating that one sense is 'focal' or 'core' and the others are extended from that. There is potential for confusion in that 'extension' can be interpreted as a diachronic process whereby at some point in time another meaning or other meanings are added; or as a notion defined without reference to change over time. ${ }^{2}$ This chapter aims to distinguish and clarify this ambiguity for the realm of kinship terminology at least.

David Kronenfeld (1996) gives a summary of work in an extensionist framework and its advantages over a 'conjunctivist' approach such as componential semantics. He particularly focuses on kinship analysis including his own work on Fanti (2009), which uses a slight modification of the Lounsbury-Scheffler framework, enabling use of both reduction and expansion rules. He presents some examples of how the Lounsbury

\footnotetext{
1 Vladimir Pericliev (2013: 15-20) describes Lounsbury's extensionist approach and other theories that have built on componential semantics. He notes (2013: 16) that the extensionist approach to kinship in anthropology goes back to Bronisław Malinowski's (1929: 525-26) idea that children first acquire the terms for elementary relationships like 'mother, 'sister' then extend them to more distant relationships to form a classificatory system. It is incorrect that the extensionism of Lounsbury and Scheffler truly relies on componentialism in defining the basic elements of kinship strings: rather they arise from relative products of elements like 'mother', 'sister' etc. (see Kronenfeld 1996: 155).

2 'Extension' has a different meaning in the philosophy of language and often in linguistic semantics, where it is contrasted with 'intension' as two ways of defining the meaning of a word. In this sense 'extension' involves a listing of the referents of a word, while 'intension' defines the word in terms of some combination of concepts drawn from a semantic metalanguage. In this theoretical discourse, therefore, the 'extension' being discussed in this chapter is a variety of intensional definition. While this is confusing, it would be more confusing to change the theoretical terminology at this point.
} 
approach handles Crow skewing (Figures 17-19; Lounsbury 1964). ${ }^{3}$ Skewing is a form of extension in which members of adjacent generations are referred to by the same term. In order to describe skewing accurately, it is necessary to combine the actual skewing rule with other rules that are of more general applicability also in systems without skewing such as Merging (Figure 17), which is the rule that plays a part in defining, for instance, Bifurcate Merging systems.

\section{Lounsbury's reduction rules for Crow-type kinship terminologies: Merging rule}

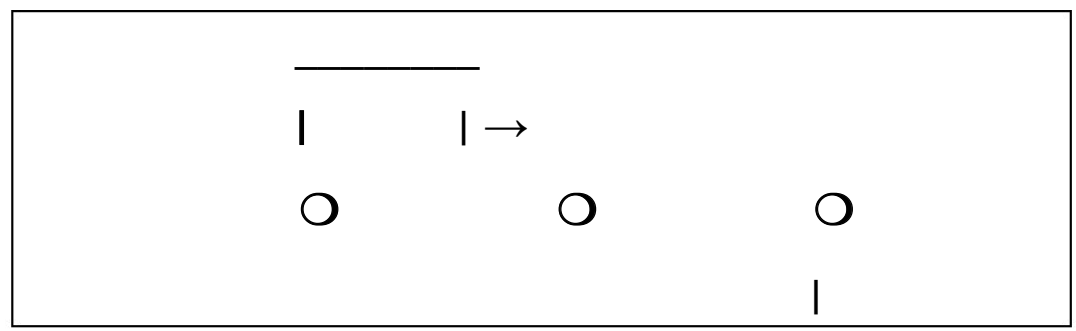

Figure 17. Somebody's mother's sister is equivalent to that somebody's mother, and reciprocally, some woman's sister's descendant is equivalent to that woman's own descendant

Source: Adapted from Kronenfeld (1996: 156, Figure 9.1) and used with permission.

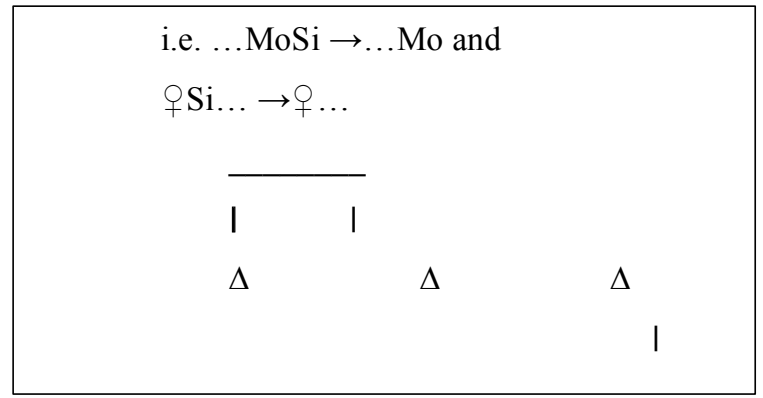

Figure 18. Somebody's father's brother is equivalent to that somebody's father, and reciprocally, some man's brother's descendant is equivalent to that man's own descendant

Source: Adapted from Kronenfeld (1996: 156, Figure 9.1) and used with permission.

3 The original notation of Lounsbury is used here. Elsewhere in this chapter, the kin abbreviations are changed from e.g. MoSi to MZ for 'mother's sister' etc. as used in the AustKin project. 
Skewing Rule (Crow-Type, Type 1)

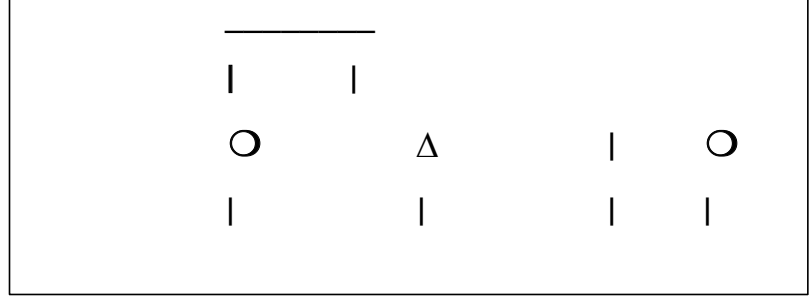

Figure 19. Somebody's mother's brother's child is equivalent to that somebody's own brother's child, and reciprocally, somebody's father's sister's child is equivalent to that somebody's father's sibling

Source: Adapted from Kronenfeld (1996: 156, Figure 9.1) and used with permission.

The extension rules can be classified into a small number of types. Such rules working together in constrained combinations can define the range of kinship systems that are known in world societies.

\section{Extension rule types: Scheffler on Australia}

Scheffler took on a major challenge in dealing with the range of Australian kinship systems in terms of the extensionist formalism in his Australian Kinship Classification (1978). The seeds of extensionism were present in A.R. Radcliffe-Brown but Scheffler went beyond the Radcliffe-Brown typology (1930-31), which had been dominant until that time.

Many found the prose of this book and the kinds of formal rules, as in the following example (Scheffler 1978: 145), dense and difficult.

\section{Example of equivalence rules for a 'Kariera' system from Scheffler}

Equivalence rules in Mari'ngar kin classification:

1. Half-sibling-merging rule $(\mathrm{PC} \rightarrow \mathrm{Sb}$ ), self-reciprocal

2. Stepkin-merging rule $(\mathrm{PSp} \rightarrow \mathrm{P})=(\mathrm{SpC} \rightarrow \mathrm{C})$

3. Same-sex sibling-merging rule $(\ldots \mathrm{m} / \mathrm{wSb} / / \rightarrow \mathrm{m} / \mathrm{w})=(\mathrm{m} / \mathrm{wSb} / / \ldots \rightarrow \mathrm{m} / \mathrm{w} \ldots)$ 
4. Parallel-cross neutralisation rule

$$
\begin{aligned}
& (\mathrm{FZ} . \rightarrow \mathrm{FB} .)=(. \mathrm{wBC} \rightarrow \mathrm{mBC}) \\
& (\mathrm{MB} . \rightarrow \mathrm{MZ} .)=(. \mathrm{mZC} \rightarrow . \mathrm{wZC})
\end{aligned}
$$

5. Parallel-cross status extension rule

$$
(\text { FFSbxC } \rightarrow \text { MSb })=(\text { PSbxSC } \rightarrow \text { ZC) }(1978: 145 \text {, Table 4.4) }
$$

Nevertheless, the idea of extension and equivalence rules captured well the polysemies in these classificatory systems and the variations between the different systems in different groups. Others, including me, have tried to use the essential insights of these schemes to come up with more general and simplified schemes such as shown in Table $2 .{ }^{4}$

\begin{tabular}{|c|c|c|c|c|c|}
\hline Code & Name & $\begin{array}{l}\text { Equation } \\
\text { (example) }\end{array}$ & $\begin{array}{l}\text { System } \\
\text { type }\end{array}$ & $\begin{array}{l}\text { Sheffler } \\
\text { number: } \\
\text { pp. }\end{array}$ & $\begin{array}{l}\text { Scheffler } \\
\text { name }\end{array}$ \\
\hline$A$ & $\begin{array}{l}\text { Merger within } \\
\text { parallel and } \\
\text { within cross }\end{array}$ & $\begin{array}{l}\mathrm{FF}=\mathrm{MMB} \neq \mathrm{MF} \\
=\mathrm{FMB}\end{array}$ & ‘Kariera' & 5: 226 & $\begin{array}{l}\text { Parallel-cross } \\
\text { status - } \\
\text { extension }\end{array}$ \\
\hline$B$ & $\begin{array}{l}\text { Merger of same } \\
\text { gender }\end{array}$ & $\begin{array}{l}\mathrm{FF}=\mathrm{MF} \neq \mathrm{MM} \\
=\mathrm{FM}\end{array}$ & 'Aluridja' & 4: 226 & $\begin{array}{l}\text { Parallel-cross } \\
\text { neutralisation }\end{array}$ \\
\hline C & $\begin{array}{l}\text { Skewing } \\
\text { (adjacent } \\
\text { generation) }\end{array}$ & $\begin{array}{l}\text { e.g. Omaha, } \\
\text { mother = cross- } \\
\text { cousin etc }\end{array}$ & 'Ngarinyin' & 5: 404 & $\begin{array}{l}\text { Omaha } \\
\text { skewing }\end{array}$ \\
\hline$D$ & $\begin{array}{l}\text { Alternate } \\
\text { generation } \\
\text { equivalence }\end{array}$ & $\begin{array}{l}\text { sibling = parallel } \\
\text { grandparent; } \\
\text { cross-cousin = } \\
\text { cross-grandparent }\end{array}$ & & 7: 226; 376 & AGA \\
\hline$E$ & $\begin{array}{l}\text { Consanguineal- } \\
\text { affinal }\end{array}$ & $\mathrm{FZ}=\mathrm{WM}$ & & 8: 226 & $\begin{array}{l}\text { Spouse- } \\
\text { equation }\end{array}$ \\
\hline$F$ & $\begin{array}{l}\text { Merger of } \\
\text { opposite-sex } \\
\text { siblings }\end{array}$ & $\mathrm{MM}=\mathrm{MMB}$ & & & \\
\hline
\end{tabular}

Table 2. Common equations and paths of semantic change in Australian kinship terms

Source: McConvell (2013c: 156).

4 The table has been slightly altered from the published version. AGA (Alternate Generation Agnatic) was included in the publication but not AGU (Alternate Generation Uterine). 


\section{Change in kinship}

\section{Extension in change}

This 'extension' can, I propose, also be extended to describe diachronic change in kinship terms, which I shall call 'extension change'. The addition of the Omaha-skewing rule (Code $\mathrm{C}$ in Table 2) can, for instance, add the meaning $\mathrm{MBS}$ to a term meaning $\mathrm{MB}$, and $\mathrm{MBD}$ to a term meaning $\mathrm{M}$. Subsequently the original meaning may be lost in some languages. By hypothesis the change is unidirectional because the extension is from for instance $\mathrm{MB}$ to $\mathrm{MBC}$, not the reverse. This is in fact what we find in all cases in Australia, based on linguistic evidence (McConvell and Alpher 2003; McConvell 2013b).

Similarly, other equivalences in Table 2 have their counterparts in diachronic change. For instance, D, Alternate Generation Equivalence, provides for the same term being used for grandparents and siblings or cousins, on a synchronic plane. There are also examples of words meaning parallel grandparent in some languages and siblings in others, for instance the widespread term kaku in Australia. By hypothesis this results from a transitional polysemy of this type in which only one meaning survives. This diachronic extension may or may not exhibit a fixed directionality of change: further research is needed to establish this empirically, for instance to determine which is the earlier meaning of kaku in Pama-Nyunganelder sibling or father's father. ${ }^{5}$

'Transitional polysemy' mentioned above is therefore the stage in a change process in which two senses of a kinship term are found together in one language at one time. Figure 20 is the general form of the process, with stage 2 being the stage of transitional polysemy. An actual example is given of the change in *kaala due to Omaha skewing.

\begin{tabular}{|c|c|c|c|}
\hline Stages: & 1 & 2 & 3 \\
\hline Senses: & A & $A+B$ & B \\
\hline \multirow[t]{2}{*}{ Example: } & kaala 'MB' & kaala 'MB + MBC' & kalay $\mathrm{MBC}$ \\
\hline & N. E. Qld. & N.W. Qld. & Yolngu \\
\hline
\end{tabular}

Figure 20. Transitional polysemy

Source: McConvell (2013b: 253-54).

$5 \quad K a k u$ for instance turns up as eB in Gumbaynggirr, on the north coast of New South Wales. 
The following sections take a look at the relationship between extension and history in two North American language families, before discussing the relationship between extension as synchronic overlay and diachronic change in general, then returning to discussion of Australia.

\section{Whistler on Wintun}

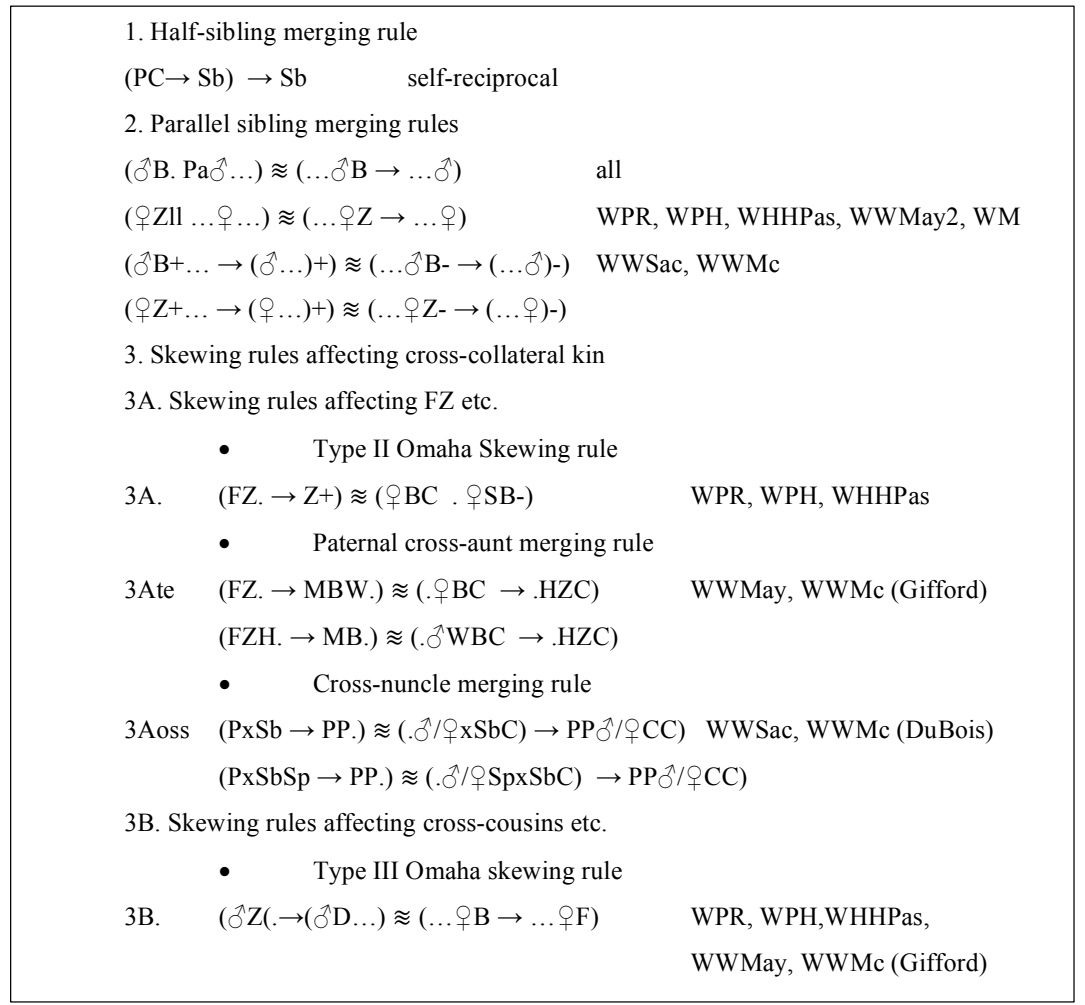

Figure 21. Extension in change: Whistler on Wintun

Source: Created by Patrick McConvell from information in Whistler (1980: 284).

The extensionist theory of Lounsbury and Scheffler has only rarely been applied to diachronic change. One example is the work of Ken Whistler in his $\mathrm{PhD}$ dissertation (1980) on Wintun kinship reconstruction (California). In Figure 21, the Lounsbury-style rules are listed on the left by name, then in the middle column the equivalence rules are stated formally. In the right-hand column are abbreviations for the languages or dialects in which each of the rule variants is found (Whistler 1980: 284). 
The most important area of variation in equivalence relates to the skewing rules. These are all of 'Omaha' type but differ from the Omaha Type I found most generally in Australia (McConvell 2013b).

George Murdock (1949) proposed a prehistoric development of kinship systems in Wintu based on an evolution set out in Figure 22. This is what Whistler calls a 'non-lexical reconstruction'-it does not take account of the form of kinship terms. By contrast Whistler's (1980: 347) reconstruction in Figure 22 is based on lexical evidence, and on this basis Murdock's proposal can be shown to be false. Whistler's reconstruction (Figure 23) of the development of different types of Omaha skewing traces its stages through a phylogeny of Wintu languages.

\begin{tabular}{|c|c|}
\hline $\begin{array}{l}\text { Murdock's } \\
\text { Explicit } \\
\text { Reconstruction }\end{array}$ & $\begin{array}{l}\text { Normal Dakota } \rightarrow \text { Neo-Dakota } \rightarrow \text { Neo-Yuman (Wintu) } \\
\text { by residence change } \quad \text { by descent change }\end{array}$ \\
\hline $\begin{array}{l}\text { Extrapolation } \\
\text { of Murdock's } \\
\text { reconstruction }\end{array}$ & $\longrightarrow$ Normal Omaha (Patwin, \\
\hline
\end{tabular}

Figure 22. Murdock on Wintun kinship system reconstruction

Source: Created by Patrick McConvell from information in Whistler (1980: 345).

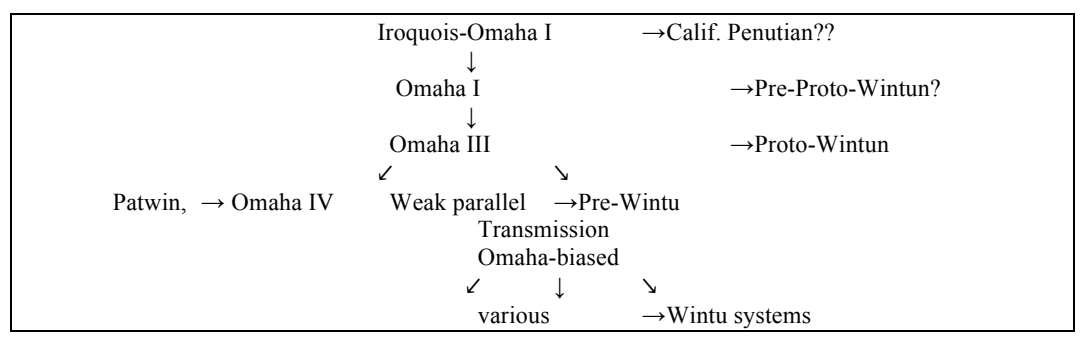

Figure 23. Whistler vs. Murdock on Wintun kinship system reconstruction Source: Created by Patrick McConvell from information in Whistler (1980: 347).

Both Omaha and Crow skewing are found more widely in California, outside the Wintuan family. The combination of Omaha and Crow that Whistler calls 'parallel transmission' is found only in some of Northern Wintuan and is reconstructed back to pre-Wintuan by Whistler. With cautious queries Whistler roots the tree in a putative macrofamily of Californian Penutian. ${ }^{6}$

6 While evidence for Penutian seems to have grown since 1980, doubts linger over membership of Wintuan specifically, with suggestions that Wintuan is an independent intrusion from Oregon in the north. 
This leaves intriguing questions about whether kinship system prehistory can be tied to proto-language stages or may involve areal groupings resulting from diffusion, or as I have proposed, from the type of migration involved (McConvell 2013b).

\section{Change, variation and overlays}

\section{Kronenfeld: Stable core and unstable extensions}

Kronenfeld (1996, cf. more general comments on change in Kronenfeld 2013) also touches on the themes of this chapter-diachrony and the contribution of historical linguistics - in a brief reference to Morgan's foundational comparative work in North America. He introduces an important hypothesis here, that 'core' meanings of terms are stable, but extensions are variable and unstable. As far as I know this has not been rigorously tested, but a number of the examples used in this chapter could be mustered to do this. His example is quite apposite for some of the material to be discussed, since it is about variation with a subgroup in North America that contains the Crow and Omaha people from whom the skewing patterns of the two types were named, as well as groups without skewing.

When one examines data on kin terminologies for a large number of related languages and cultures—as is assembled, for example, in Morgan's data on the Dakota Indian groups (within his Ganowanian 'family' [1871: Table-Appendix to Part II, pp. 281-382]) — the following facts emerge $\ldots$ if we use the full (that is, extended) range of referents (denotata) of these terms to infer their signifieds (related to their significata) we find a very bad match, since the languages show very different patterns of extension. Some of the languages have patrilineally skewed Omaha-type terminologies; some have matrilineally skewed Crow-type terminologies; and some have unskewed Iroquois-type terminologies. Indeed, the actual Omaha Indians and Crow Indians, for whom the two opposed types of skewing are named, are closely related members of a Dakota subgroup that also includes the Yankton and Oglalla Dakota (Sioux) Indians, who have unskewed terminologies. However, contrary to the picture we get for extended ranges, when we limit our comparison to kernel or focal kintype referents we find an extremely good match across the whole Dakota group ... 
Since the languages involved are fairly closely related, we know that they have each relatively recently developed out of a single, common ancestral language. The period of time involved has not been sufficient for the terminological labels (signifiers) or the focal referents (pointed to by the signifieds linked to each of these signifiers) to drift very far apart. But that same period of time has been quite adequate for great changes to occur in the extended ranges and thus in the extension operations (or rules) that produce these ranges (that is, extend them from the kernels). Thus we have diachronically based comparative data that supports the same contrast between relatively fixed, constant focal referents and more variable extended ranges that we found synchronically within the single Fanti system (Kronenfeld 1996: 164).

\section{Kronenfeld on synchronic variability}

This passage should be read in close association with Kronenfeld's other comments on synchronic variability. In Fanti, he identifies three types of patterning of kinship terminology in use in the community:

1. The 'courtesy' pattern: some terms are used to recognise relative age without genealogical specification.

2. The 'unskewed' pattern is restricted to actual kin, and includes more genealogical information on generation, relative age, gender and side of the family.

3. The 'skewed' pattern is most marked and is distinguished from 'unskewed' by the addition of a Crow-type skewing rule to the set of extension rules; Fanti say that the equation of 'mother's brother' and 'sister's son' exists because of inheritance by the latter from the former (1996: 161).

While there are factors which tend to induce one or other of these patterns to be used, he stresses that these are not unbreakable social rules but leave some role for individual choice and agency. He gives an enlightening example:

In terms of usage and communication-Saussure's parole-we note that the use of particular patterns of extension is not limited to the social contexts that occasion them, but rather that every pattern is available at all times ... Within a given conversation, different speakers may use terms from different extension patterns-that is, may use terms nonreciprocally-even if the one person's usage becomes part of the context for the other person's choice of term. 
Thus the terminology with its variant forms as a part of langue provides sets of regularities, that is, patterns, which speakers are free to use as suits their purposes. This point was brought home to me when I observed a pair of Fanti cross-cousins nonreciprocally addressing each other-as 'father' in one direction, and as 'brother' in the other (see Kronenfeld 1970: 104-07). I knew from other interviews with them that both men knew (and stated) that the 'correct' reciprocal of 'father' was 'child' and of 'brother' was 'brother'; thus the usage I observed did not result from any lack of awareness of the pattern or from any resistance to it. Further investigation revealed that since they were close kin they felt they had to use kinterms in genealogically correct forms, instead of the nongenealogical mode of the courtesy pattern; such genealogically correct usage also emphasized the genealogical link, which, I gather, they wanted to do. At the same time, since they liked and respected each other, each man was anxious to show the other as much respect as he could - and so each man, in addressing the other, picked the highest status term out of the set available to him for that genealogical position. Thus, one man picked 'father' (from the skewed extension pattern) over 'brother' (from the unskewed pattern), while the other man picked 'brother' (from the unskewed pattern) over 'son' (from the skewed pattern). Their goal in this conversation was not to be correct, but to communicate their messages as effectively as possible with the resources that their language afforded them (Kronenfeld 1996: 162-63).

While this kind of flexibility is valuable in providing a means of sending subtle social messages to conversation participants and audiences, it may have a cost in the stability of the overall system (Kronenfeld 2013: 35). Children may reinterpret a system if its performance does not provide enough evidence for how it is operating to the children at the time when they are acquiring it.

It seems quite likely that such intergenerational mismatches lie behind the changes that I am discussing in this chapter. However, we do not in most cases have direct evidence of the social mechanisms of processes of change that may have occurred hundreds or thousands of years ago in such places as precolonial Australia or North America. We can know what happened, especially because of the evidence of historical linguistics, but finding out how it happened in social terms is more difficult. 


\section{Hypothesis that all changes are explained by extension}

This chapter proposes a strong hypothesis that all diachronic changes in kin-term meanings in Australia can be explained as addition of, or loss of, reduction rules as formulated by Scheffler, or minor variations or sequential combinations of them. The ideas of Kronenfeld about contextual variation and overlays (section above) in extension patterns are also crucial in explaining transitions in kinship system change in Australia.

In the next section, examples of sequences of kinship system change that conform to this hypothesis in Australia are presented, introduced by an overview of the database tool we use to provide evidence, AustKin.

In the section following the next, examples are raised that do not conform to the hypothesis that all diachronic change in kin-term meanings results from extension. Possible reasons for such exceptions include altercentricity, such as filiocentricity.

\section{Australian examples of semantic variation and change}

\section{The Austkin database}

The kinship terminology data in this paper is obtained by standard linguistic comparison of forms of kinship terms across regions, and the whole of Australia, using the database AustKin (Dousset et al. 2010; McConvell and Dousset 2012). The searches used include equivalences (e.g. where does the word for MB also mean MBS?) and for forms of words (e.g. where is the form kaalalkala + found and what is its meaning?). These and other combinations and customised results can be matched and mapped using Google Earth, AustLang (ANU/AIATSIS) or other GIS programs.

\section{Omaha skewing and asymmetry}

Omaha skewing is a form of extension that has led to an extension change in Australia several times with different kinship-term forms. Figure 24 illustrates how the sequence plays out, beginning with 'overlay' skewing 
in which the skewed forms for MBS may only occur optionally or in particular context. In the next stage skewing may solidify so that the extension (MB to MBS, MBD in this example is always used) followed by loss of the form for the original meaning. We do not go into how this last stage happens in detail. In Yolngu Matha for instance, in most dialects a loanword has been brought in from a non-Pama-Nyungan neighbour, ngapipi for the meaning MB.

\begin{tabular}{|c|l|l|l|}
\hline \multicolumn{5}{|c|}{$\rightarrow$} \\
\hline$M B$ & \multicolumn{1}{|c|}{$M B$} & \multicolumn{1}{c|}{$M B$} & \multicolumn{1}{c|}{$M B$} \\
\hline$M B S$ & $M B S$ & $M B S$ & $M B S$ \\
\hline No skewing & Overlay skewing & Full skewing & $\begin{array}{l}\text { Shift to skewed } \\
\text { meaning }\end{array}$ \\
\hline Two separate items & $\begin{array}{l}\text { MB used for MBS } \\
\text { under some conditions }\end{array}$ & $\begin{array}{l}\text { MB used for MBS } \\
\text { unconditionally }\end{array}$ & $\begin{array}{l}\text { Original MB term } \\
\text { replaced }\end{array}$ \\
\hline
\end{tabular}

Figure 24. A diachronic sequence of Omaha skewing in Australia Source: McConvell (2013b: 253-54).

Figure 25 shows where reflexes of the term *kaala, originally MB in protoPama-Nyungan, ${ }^{7}$ occur in Australia. The original meaning MB is found in northeast Queensland and there are some instances of skewing of this term to MBS or MBS in this area also. The unskewed meaning is also found in southeast Queensland, but other than that the meaning has changed; in the west (including Yolngu) and south, the skewed meaning (MBS, MBC) only is found. ${ }^{8}$

The diachronic interpretation is that skewing began in the northeast but as the term spread out to the west and south, with the expansion of PamaNyungan, the skewed meaning took over for the kaala reflexes and the MB meaning was lost (replaced by other forms).

In some cases the meanings of the skewed (cross-cousin) reflexes of the root have either the extension of spouse or some sibling-in-law or have changed completely to the affinal meaning. This type of extension is acknowledged by Scheffler as 'spouse-equation' and assigned Type E

7 Pama-Nyungan is by far the largest language family in Australia covering most of the continent except for the Central North. Yolngu Matha is an outlier of Pama-Nyungan surrounded by nonPama-Nyungan languages in Northeast Arnhem Land.

8 In northern New South Wales between the areas of nonskewed meanings to the north and skewed meanings to the south, there is a case of active skewing in Gumbaynggirr (Morelli 2008). This involves the root kawa (probably cognate with *kaala (MB extended (as a contextual overlay) to MBC. 
in Table 2. This provides an indication that either in the present or at some stage in history (some type of) cross-cousin was a marital partner, although marriage rules may have changed since that time.

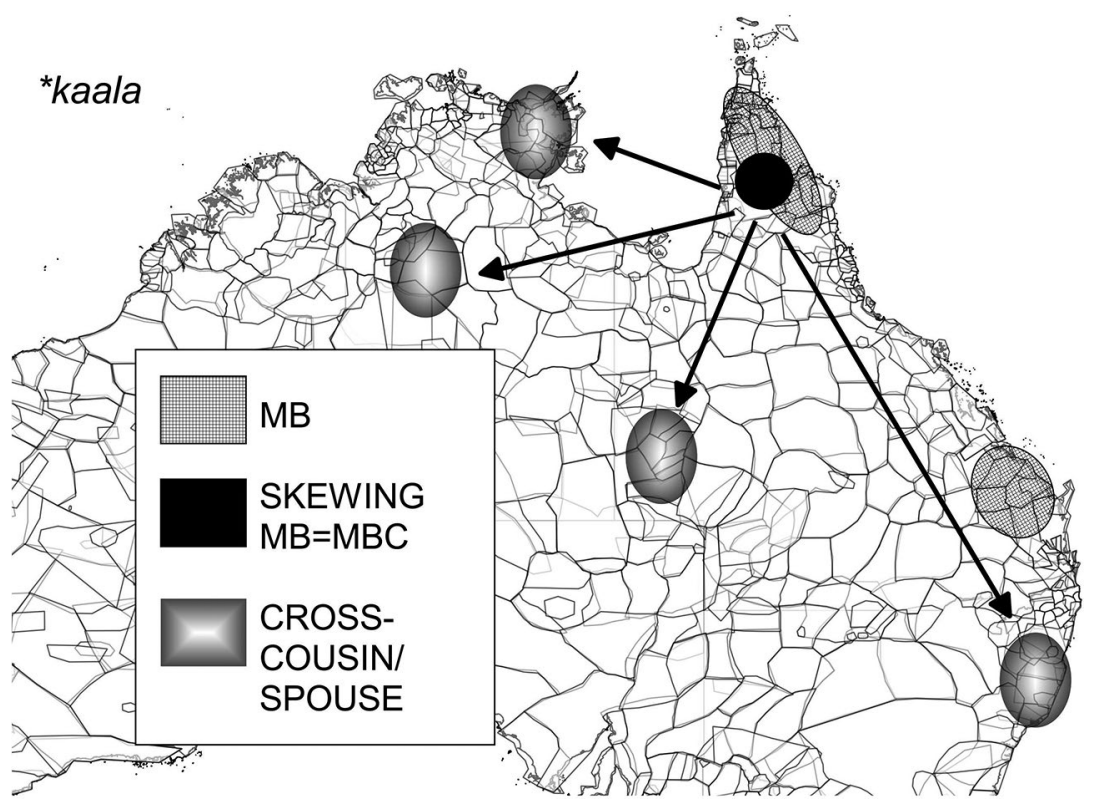

Figure 25. Kaala MB > Cross-cousin/spouse

Source: McConvell (2013b: 254). Mapping from AustKin @ Patrick McConvell and William McConvell.

The Omaha extension has a corollary. Seen from the other end of the extension the female's child or sister's child extends up a generation, to mean father's sister's child (patrilateral cross-cousin). This too has a diachronic extension change. In the case of kaala, the corollary is found with *tyuwa+ proto-Pama-Nyungan for female's child. The pattern of spread and change in meaning of this root is quite similar to that of *kaala and is shown in Figure 26.

Again the original meaning ( $\mathrm{fC}$ ) is found in northeast Queensland, with skewing to FZC found in some languages, and to an extent south of there in Queensland. Other western attestations have changed to the skewed meaning FZC, as in Yolngu, which also has the meaning of husband (and his siblings) in the unilateral marriage system there. In the far west, cognate forms mean the affinal kin types $\mathrm{HZ}$ and $\mathrm{BW}$, derived by the affinal extension change from the intermediate cross-cousin meaning. 


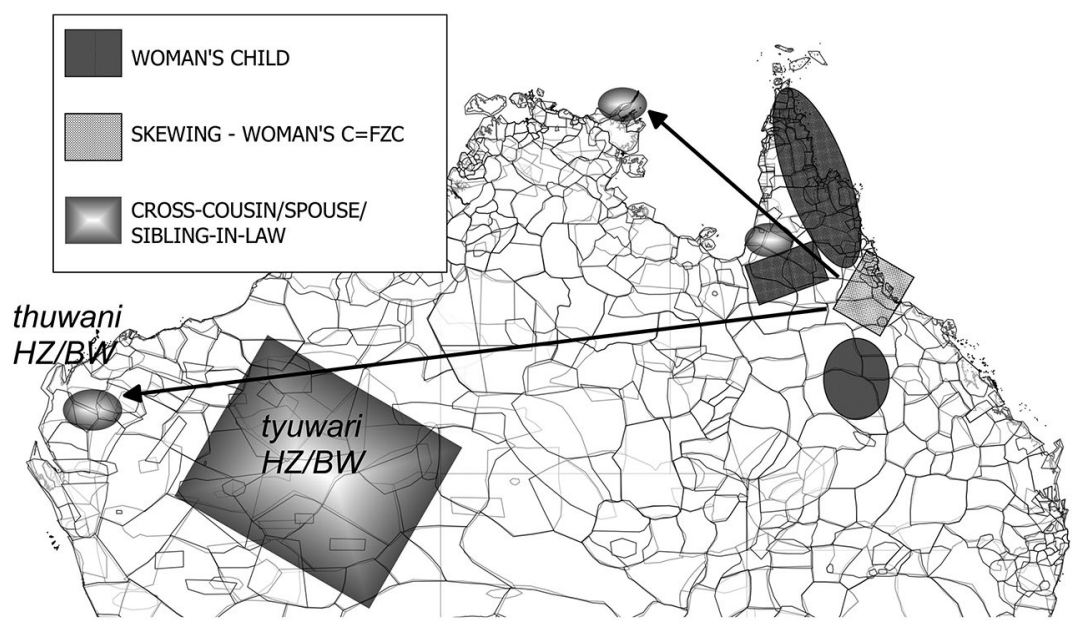

Figure 26. *tyuwa+: Woman's child > FZC > Sister-in-law

Source: McConvell (2013b: 255). Mapping from AustKin (c) Patrick McConvell and William McConvell.

\section{Loss of cross-parallel distinctions}

Another important type of extension change is the loss of cross-parallel distinctions, called 'parallel-cross neutralisation' by Scheffler, and listed as Type (Code) B in Table 2. This was a type of change which was proposed by the first scholars to work on Australian kinship, Fison and Howitt, in their book Kamilaroi and Kurnai (1880). The latter group, in Gippsland, Victoria, was notably different from the Kamilaroi and other groups known to them, because the Kurnai called their cross-cousins 'siblings', not some distinctive term. This is an example of cross-parallel neutralisation in the zero generation, but among the Kurnai this did not extend to other generations like the grandparents. This kind of restriction of cross-parallel neutralisation to the zero generation rather than the 'Hawaiian' system where there are no cross-parallel distinctions in any generation, is not uncommon world-wide: Gertrude Dole called it 'bifurcate generational' (1969: 118). ${ }^{9}$

9 Fison and Howitt did not have linguistic or convincing ethnological evidence of this direction of change in Gippsland but relied on assumptions that the Dravidianate systems elsewhere must have been primordial on the one hand, and a highly speculative story of how people arrived in Gippsland on the other (Fison and Howitt 1880; Gardner and McConvell 2015). Intriguingly, Lorimer Fison later rejected his own story about this, claiming that he had received 'new evidence'-but there is no account of this evidence (Fison 1892). 
In the Western Desert, the so-called 'Aluridja' system also features crossparallel neutralisation in the zero generation, but as Laurent Dousset (2003) has shown, it is actually a contextual overlay used to talk about people who are not marriageable, and this often depends on the state of relations between groups, not hard and fast rules. This kind of division of cross-cousins into the unmarriageable 'siblings' and the marriageable classificatory cross-cousins is found in other groups. Among the Kija the latter group are thamany-MF('s siblings). It may be though that for other groups like the Kurnai, this was once a transitional stage but then the naming of cross-cousin 'siblings' became categorical. ${ }^{10}$

The Western Desert (unusually for Australia) also has cross-parallel neutralisation in the +2 or grandparental generation, such that there is a term tyamu, which is like English 'grandfather' in referring to both maternal MF and paternal FF; and kami (and kaparli in different dialects) like English 'grandmother' referring to both maternal MM and paternal FM.

Omaha skewing, discussed earlier, seems to correlate with what I have called 'encroaching or downstream spread' and loss of cross-parallel distinctions with 'skirting or upstream spread'. Details of why these correlations are present still need to be worked out (McConvell 2013b).

Cross-parallel distinctions in grandparent terminology are also lost under apparently similar circumstances yielding grandfather/grandmother systems from systems which distinguished FF and MF and FM from $\mathrm{MM}$, for example in the Chiracahua variety of Apachean (Dyen and Aberle 1974), and inland Northern Athapaskan (Ives 1998), as well as in the 'Aluridja' system of the Australian Western Desert. The restricted distribution of this kind of system in Australia can be seen in Figure 27. ${ }^{11}$

10 This kind of change does not seem to move on to a stage when the original meaning of the term is lost, as far as I know. That would mean that an original term meaning 'sibling' came to mean 'cross-cousin' only. Preliminary investigation does not reveal any such pathways.

11 It is also found to some extent in the Bandjalangic languages of the eastern QueenslandNew South Wales border. 


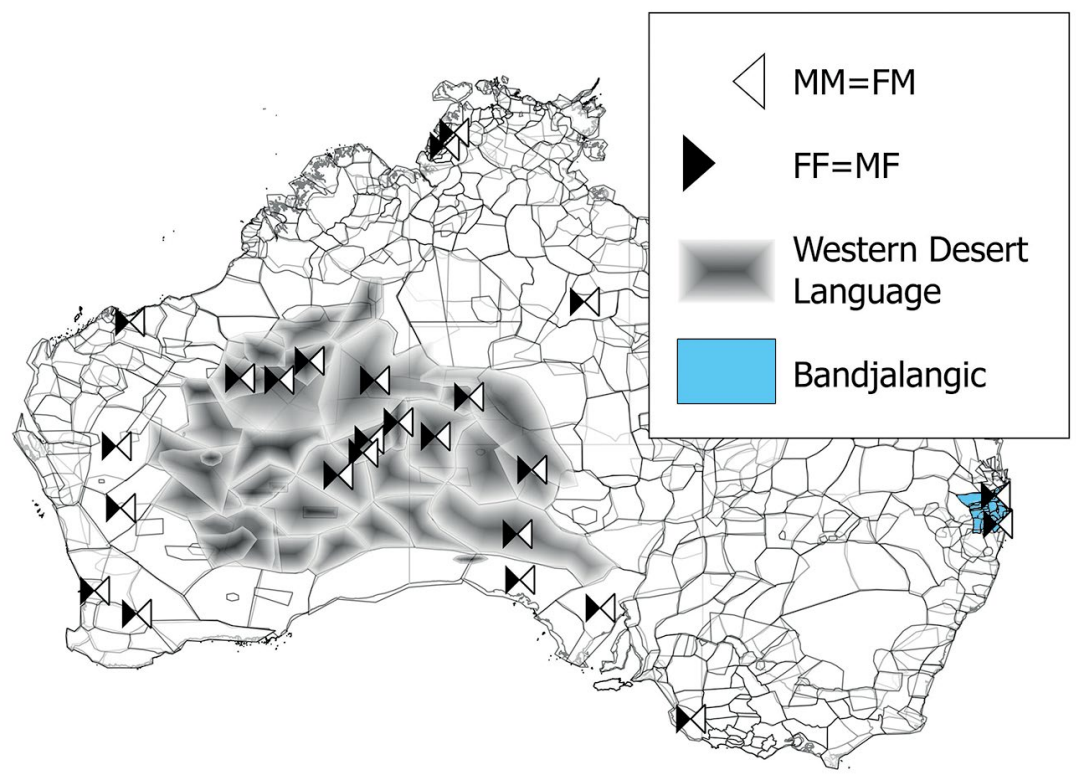

Figure 27. Aluridja grandparents

Source: Mapping from AustKin (c) Patrick McConvell and William McConvell.

Thanks to linguistic reconstruction we can be sure of the original sources in the proto-Pama-Nyungan or some high-level proto-language within Pama-Nyungan.

Tyamu clearly derived from an old Pama-Nyungan root meaning MF (McConvell 2013a) so was extended to FF in the Western Desert. In particular, tyamu or related forms are found in the Pilbara languages north of the Western Desert. The region where both icons are found for the same languages are where there is $\mathrm{MF}=\mathrm{FF}$, and $\mathrm{MM}=\mathrm{FM}$, which is roughly conterminous with the Western Desert (see Figure 28).

Kami is found in a wide area of Pama-Nyungan, including in the eastern states, in the meaning MM and can be reconstructed as MM, so must have been extended to FM in the Western Desert. ${ }^{12}$ Similarly kaparli is found widespread as FM and must have been extended to MM (see Figure 29). The region where both icons are found for the same languages are where there is $\mathrm{MM}=\mathrm{FM}$, and is roughly conterminous with the Western Desert.

12 There is an area in Lake Eyre Basin where kami means FM, but this is clearly an innovation (McConvell 2013c) and is unrelated to the Western Desert change. 


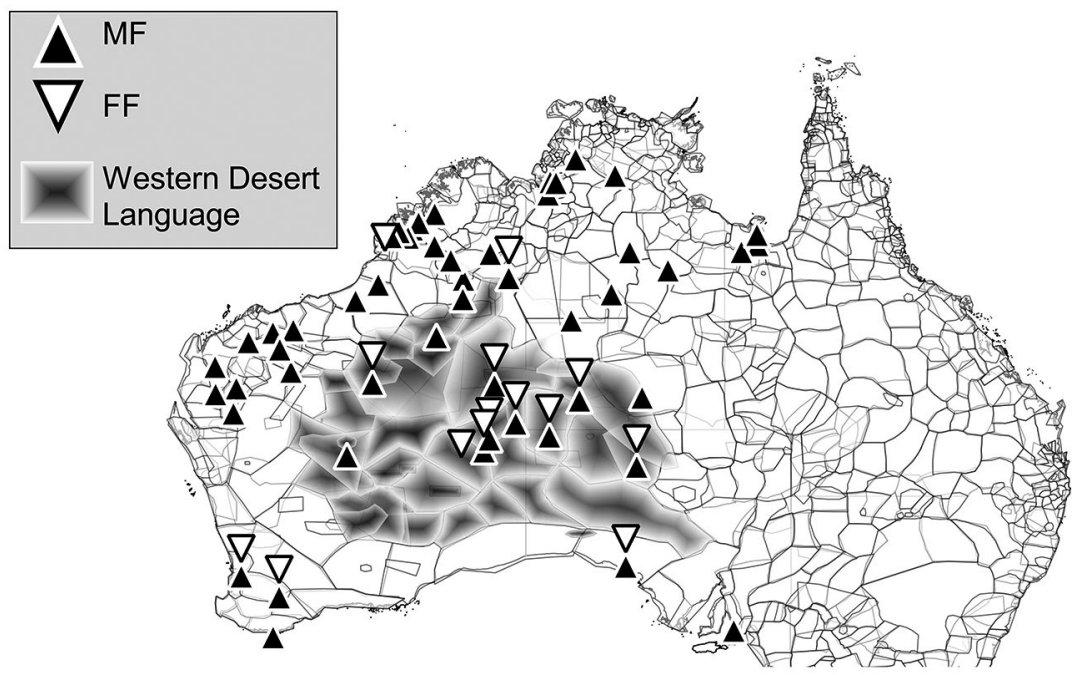

Figure 28. *tyamu MF > MF + FF in Western Desert

Source: Mapping from AustKin (C) Patrick McConvell and William McConvell.

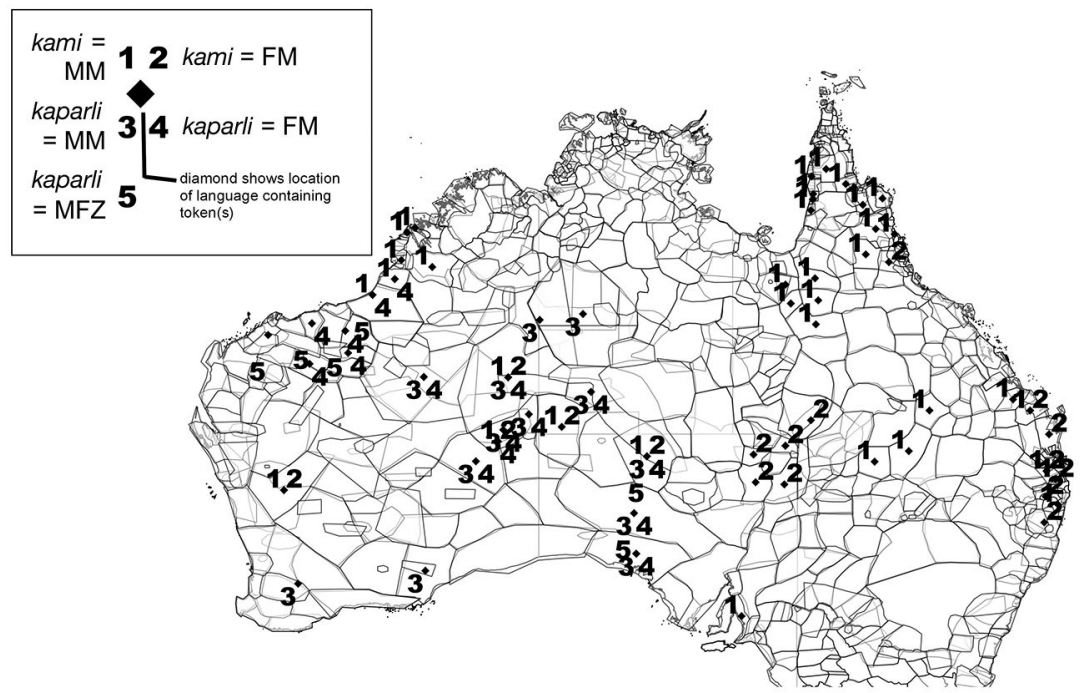

Figure 29. Kami and Kaparli

Source: Mapping from AustKin (C) Patrick McConvell and William McConvell.

Figure 30 shows how the extensions of grandparental terms occurred historically in the Western Desert. A hypothesis that the change went in the opposite direction would be completely implausible. 


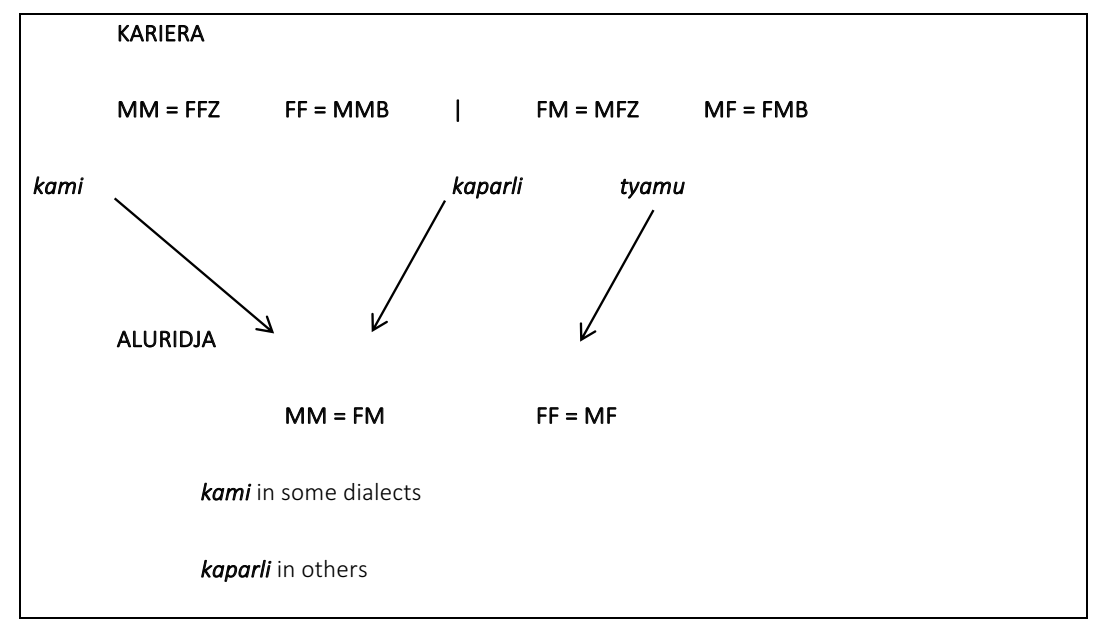

Figure 30. Kariera to Aluridja

Source: Drawn by () Patrick McConvell, 2017.

\section{Cases not covered by the hypothesis}

\section{Introduction}

This hypothesis, that changes in kinship meaning result from Schefflerian extensions that are found in transitional polysemies, stands up fairly well. But there are a number of cases where change of meaning of a term is evident but which cannot be explained in terms of Scheffler's proposed extension rules, and/or do not display evidence of the classic pattern of transitional polysemy.

Two types of change are noted here that do not display the classic pattern of transitional polysemy:

1. change of gender of +1 (parental) generation terms, affines or with affinal equivalences, and

2. change of one generation down, from sibling to child, unrelated to any known skewing pattern. 


\section{Change of gender of +1 (parental/affinal) generation terms}

There is a term which began as ramparr in the North Kimberley region of Western Australia, diffused southwest, then, changing to lamparr due to a regular sound change, diffused west across the south Kimberley and a long distance into the Northern Territory (McConvell 2015).

The most problematic part of the history of ramparr is the change of the term from mother-in-law and her brother in west Worrorran and eastern Nyulnyulan to father-in-law in eastern Nyulnyulan. While these meanings both refer to parents-in-law, the change from WM(B) to WF is unexpected. Significantly, a change from mother-in-law to father-inlaw apparently represents a contravention of a principle of transitional polysemy in semantic change set forth by Nicholas Evans and David Wilkins (2001) that I further developed in relation to kinship terms (McConvell 2013a). While many changes in kinship-term meanings do show these properties of transitional polysemy in Australia, there is doubt about whether mother-in-law and father-in-law share the same term anywhere, even in any of the Kimberley languages under discussion.

However, in this case, as we have noted, in its early history the term ramparr has a wider meaning of an avoidance relationship which encompassed several types of in-laws who may also be designated by more specific kinship terms, probably emerging from an original concrete meaning of 'barrier' extended metaphorically (McConvell 2015). This may be then a case of a term in which there is what we might call hypopolysemy. That is, one of two meanings involved is broader and includes the other narrower meaning. This is common as a synchronic pattern in fauna terms in Australia and also explains a semantic shift from the generic term for a life form to a species term or vice versa (McConvell 1997).

There is at least one more fairly clear case in Australian kinship where a similar change has happened. In Cape York Peninsula (Paman subgroup of Pama-Nyungan) the term *mukVr means 'mother's brother', but in the rest of the country where cognates of the term are found (mainly in Pama-Nyungan) it means 'father's sister and/or wife's mother' (McConvell and Keen 2011). Where the primary meanings of the terms seem to be consanguineal, they also both have affinal senses deriving from the rules of marriage: the equation FZ $=\mathrm{WM}$ is quite widely distributed in Australia 
especially where there is or was a Kariera system and cross-cousin marriage. The common ground between MB (WF) and FZ (WM) could be their key role as decision-makers about their daughter's marriage. ${ }^{13}$

\section{Change of one generation down, from sibling to child}

Another different kind of example that does not conform to what the hypothesis predicts is a change of the term katya from 'brother' quite generally, to 'son' in the Western Desert and neighbouring regions. Unlike the standard extension cases there appears to be nowhere where the term means both 'brother' and 'son'-but see the next section for a possible example of a parallel change in a root that gives insight into the process involved.

Figure 31 shows the distribution of forms cognate with katya in Australia. In Western Australia, the forms in the north in the Pilbara in the Ngayardic, Kanyara and Mantharda subgroups of Pama-Nyungan have the meaning 'elder brother'. Most of these have the form katya but some have kaya in languages in which there is a regular sound change of medial lenition *ty > y. South of there in the Wati (Western Desert) and Kartu subgroups, the form means 'son', with a couple of instances on the periphery where it is extended also to 'daughter'. ${ }^{14}$

There are a number of other instances of katya meaning 'elder brother' in eastern Pama-Nyungan subgroups which, taken together with the western distribution, open up the possibility that this is a proto-Pama-Nyungan form in this meaning. This reinforces the idea that 'elder brother' is the earlier meaning and the meaning 'son' or 'child' is the innovation in the Wati-Kartu subgroup.

13 However, unlike in the case of earlier broad meanings of ramparr that refer to a range of affines who have a hand in marriage decisions, there is no similar evidence to hand so far with regard to *mukr. 14 In a Nyungar dialect Minang, the form kotya, presumably cognate, means 'elder brother'. Unlike some other instances of katya in the Western Desert periphery, which are loans from Western Desert, this points to the 'elder brother' meaning being present in south-western as well as eastern Australia. Forms like katyakatya for 'child' are found areally around the southern Gulf of Carpentaria, but this may have a different etymology. Similarly, kaathu is 'man's child' in Yolngu Matha, but its cognacy with *katya elsewhere cannot be guaranteed. 


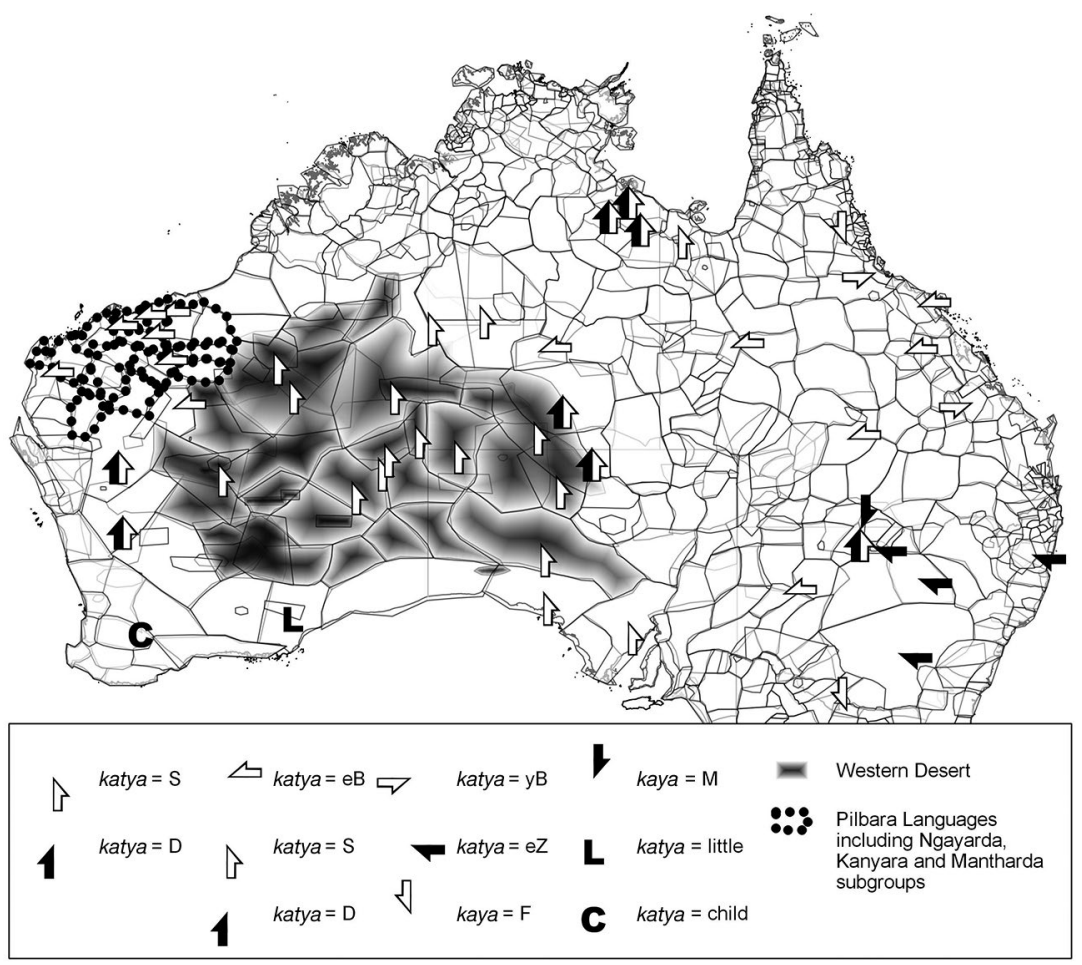

Figure 31. Katya brother > son

Source: Mapping from AustKin (c) Patrick McConvell and William McConvell.

In our extensive survey of kinship terms in AustKin, in no case does the reflex of *katya have both senses 'elder brother' and 'son/child' in the same language. This differs from the cases where there is such 'transitional polysemy' discussed above. Another difference is that while the earlier examples can be related to extensions proposed by Scheffler or similar, there is no known extension of 'elder brother' to 'son' discussed in the literature. This is a relationship between two adjacent generations but not any of the types of skewing have been analysed.

We now move on to examine what can be the cause of this meaning change if it is not related to standard types of extension. Other apparent examples of change from 'brother' to 'son/child' in Australia are then scrutinised for clues about the underpinnings of this process. 


\section{Altercentricity - filiocentricity}

Altercentricity is a term usually used for where there is no propositus indicated (e.g. Where is Mum?) and where the propositus as pragmatically inferred is other than the speaker, for instance 'your' (e.g. Mum in the example is taken to be 'your mother').

Such pragmatic inference is commonly found in languages around the world. Francesca Merlan (1982, 1989), however, looked into whether there are general principles that predict whether such interpretation is egocentric or altercentric for the Australian Aboriginal language Mangarrayi. She proposes the Juniority-Seniority Principle:

A senior speaker, in talking to a junior relative (especially a young child), tends to refer to third persons in terms of the junior's relationship to them.

A junior person (again the norms are clearer where this is a young child) in speaking to a senior relative tends to refer to others in terms of his own relationship to them (Merlan 1982: 127-28)

Murray Garde confirms the general validity of this principle in Western Arnhem Land. In other words, children addressing senior relatives speak egocentrically in referencing others, and senior kin reply to them using altercentric terms, for example, (child to father) 'Where is Mum?' (father to child) 'Mum is in the garden' (Garde 2013: 119). This is not unfamiliar to speakers of English and many other languages around the world (see Agha 2007: 350, 63).

Filiocentricity is the resulting pattern where the term used converges on the form used to and by the child in a parent-child dyad. This is therefore a term used in a narrower sense than the term teknocentricity, which refers to a more general use of terms from the point of view of children in a wider grouping, say a whole family group. The particular type of historical shift between sibling and child meanings discussed here is related to the narrower type-filiocentricity. Whether there are other change phenomena related to the broader scope of teknocentricity is not investigated here.

In Garde's data from Bininy Gunwok (again not unfamiliar from many other languages), address (vocative) kin terms can be used as referential too (Garde 2013: 51, reporting a telephone conversation). 
Child: Ngudda ngabba?

2sg father VOC

Is that you, Dad?

DjNg: Yoh.

Yes.

Child: [to others] Ngabba ... ngabba Manawukan

F.VOC F.VOC [place]

It's Dad, Dad in Maningrida

How does this relate to our problem of explaining the change of katya 'elder brother' to 'son' in the Western Desert? One possibility is that this change is mediated by a pragmatic context of 'filiocentricity', that is fathers, or more generally parents, were using the 'brother' term to their children to mean 'your brother/my son' and the main sense of the word became 'son'.

Robust reconstructions of the changes in meanings of kinship terms can be proposed based on linguistics. Most of these changes are diachronic versions of Schefflerian extensions. They involve transitional polysemies (equivalences).

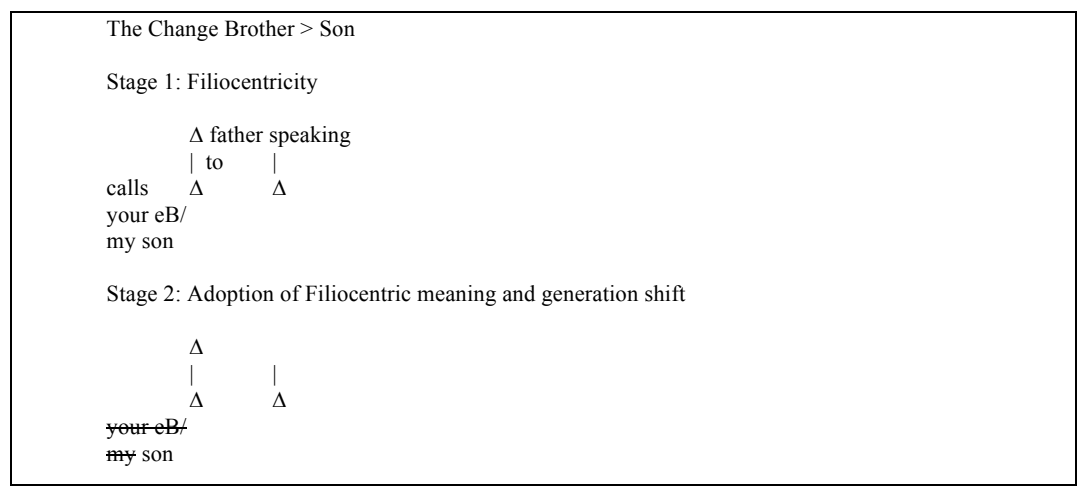

Figure 32. The change brother $>$ son

Source: Constructed by (c) Patrick McConvell, 2017.

However, filiocentric changes such as the one found in katya 'brother' $>$ 'son' do not show the same kind of transitional equivalences. The two senses of the term that is changing are not found as alternatives in the same language in the intermediate stage in the same way. Rather, I propose that the source of the split is in the centricity of the term's use. This may be 
'shifting' (Garde 2013) and the diachronic consequence of this may be a loss of the original meaning and replacement by a meaning associated with filiocentricity. The hypothesised process is shown in Figure 32.

The term for 'elder brother' in Western Desert was kurta subsequent to this change. This term is also found throughout the Pilbara mainly for 'elder brother' but occasionally for 'younger brother'. In those languages that have both katya and kurta in the meaning $\mathrm{eB}$ it would be useful to establish if there is or was a semantic difference or if there is a pragmatic difference of the two which contributed to the meaning change in katya.

There is one piece of evidence in a Western Desert language that may be relevant to this transition of katya, although it relates to kurta, the current word for eB. The Pintupi dictionary gives the phrase kutyu kurta, literally 'one elder-brother', as meaning 'oldest son' (Hansen and Hansen 1992: 43). This is taking a filiocentric view of relative age among brothers.

\section{Brother > son elsewhere in Australia}

There are a number of indicators that the kind of change from brother to son described in the last section for Western Desert is not alone of its kind in Australia. While the notes below on these other cases (drawn from the AustKin database) are of a preliminary nature, they do tend to support the idea that this is not an anomalous exception but part of a more general phenomenon.

In southeast Queensland the term tyatya is recorded as $\mathrm{eB}$ in a number of Waka-Kabi languages, with probable cognates elsewhere in southeast Australia. Nils Holmer (1983: 147-59) records the meaning 'son' in a Kabi language Gubbi-gubbi.

In Paman languages of northern Queensland, some (Kuku Ya'u, Umpila) have yapu in the meaning $\mathrm{eB}$, while further south in the rainforest Wargamay has yapu-tyu as 'son' (-tyu being a common kinship suffix in Pama-Nyungan descending from an enclitic form of 'my' (McConvell 2008: 318-21). Another word for 'son' in neighbouring and related languages yumurru, has become a form for 'son' in Wargamay used by the referent's mother 'to avoid using his name' (Dixon 1981: 124). 
In the Maric subgroup of languages, Warungu and Gugu-Badhun in northeast Queensland near to Townsville have mukina eB, and Gunya, a long distance away to the southwest has mukana 'son'. Between these, Wadjalang near Blackall has mutyi(nu) eB. This is a plausible cognate as $\mathrm{k} / \mathrm{ty}$ correspondences are found in Maric and neighbouring languages. Further, there are possible cognates in Bandjalangic on the eastern Queensland-New South Wales border all in the meaning 'son', some mutyum with medial ty (Bundjalung, Waalubal, Yugambeh) and others muyu(u) $m$ with medial y, due to regular lenition between the dialects.

In South Australia, in the Turra-Yurra subgroup, the form yunga (sometimes with a suffix) is the word for $\mathrm{eB}$, but in one language at least, Turra, this means 'son'.

On the north coast of New South Wales, in Gumbaynggirr, there is an example which shows more variation in the forms used for kinship terminology, not only for elder brother and son, but other terms. This relates to the discussion earlier of 'overlays' in kinship, and may also illustrate at least a nascent form of a trirelational system. This has been discussed in some detail for some languages of northern Australia (e.g. Garde 2013 for a summary) but has not yet to my knowledge been positively identified for southern Australia. In a trirelational system the kinship terms vary not only according to the relation between the speaker and the referent, but additionally depending on the relation between the speaker and the propositus (or addressee). ${ }^{15}$ So a term might be translated, for instance, 'my son, your brother' and a different term would be used for 'my son, your mother's brother'. This obviously adds a new dimension, and potentially many terms, to a kinship terminology.

This type of arrangement can be linked to the discussion of altercentricity. As Jeffrey Heath writes:

Whenever speaker $\mathrm{S}$ and addressee $\mathrm{A}$ are both related to a referent $\mathrm{R}$, there is a choice between egocentric ('my ...') and altercentric ('your ...') perspectives. Actual usage may be controlled by pragmatic principles, but these can be intricate (Merlan, 1982). The forced choice between the two perspectives is obviated in some Australian languages in which 'triangular' kin terms simultaneously specify S's and A's relationships to R (2006: 216; here 'triangular' is used instead of 'trirelational').

15 In some languages it seems the third factor is limited to the addressee but for others it includes third-person proposituses. 
Some of the discussion of Gumbaynggirr suggests something akin to such a system, but calls the terms involved in the variation 'avoidance' (Williams, Walker and Morelli 2014).

Juulu is a word for 'brother' used by, or in the presence of, a person who is of the right section to marry the 'brother' (usually gagu). In the following a woman is introduced by the younger brother to his older brother (ordinarily called gaguuga) to her husband-to-be. It only occurs in Nymboidan.

\section{Man to woman}

$$
\begin{array}{lll}
\text { Yang } & \text { nganyu } & \text { juulu } \\
\text { that } & \text { 1SG.GEN } & \text { brother.AVOID }
\end{array}
$$

'That's my brother'

However, the avoidance term for 'brother' juulu is only used in the presence of the referent. Where a man talks about his absent brother to women marriageable to him he uses the nonavoidance term for 'brother', but with polite pluralising of the term for 'brother':

$$
\begin{array}{lll}
\text { Yarrang-anga } & \text { gagu-urra } & \text { ngayinggi-ng! } \\
\text { that.there-PL.INDF } & \text { o.brother-PL.POL } & \text { sit-PST }
\end{array}
$$

'That's about where my brother lives.'

So, this is like a trirelational term which has a meaning 'my brother/your potential spouse' (with apparently additional conditions about presence/ absence of the referent).

There are also other words apart from these two for 'elder brother' in Gumbaynggirr: kuyu 'brother' and kuyumpan 'elder brother' (Morelli 2008). Whether these are trirelational or under which conditions these are used is not clear.

There are other kinship terms in Gumbaynggirr that are more overtly recorded as having variants that are either vocative/addressee forms or depend on the addressee/propositus (i.e. quite likely trirelational), such as kura (Morelli 2008: gura, son, when parent talking to him). There is a possible cognate in Guwar of Moreton Island (which is connected to the languages further south) kuran meaning 'elder brother'. This could then be another example of a change from eB to $S$, and the reference to 'parent talking to him' would fit with the scenario proposed for the change. 


\section{Conclusions}

This chapter began with acknowledging the ground-breaking contribution of Lounsbury and Scheffler in establishing the idea, and a formalism to express the idea, that extensions are a central part of kinship semantics. They are regular and logical and can be reduced to a small number of rules, which are in most cases found in many languages. Scheffler took this further and provided a thorough application of this idea and formalism to Australian Aboriginal kinship.

This chapter has referred to cases in which it has been shown, in the Australian context as well as elsewhere, that historical change in kinshipterm meanings is also primarily based on the kind of extension Scheffler described. This is also allied to the notion that such changes pass through a stage of 'transitional polysemy' arising from kinship extension of a limited number of types.

Finally, cases were examined where these notions of extension and transitional polysemy are difficult to apply. Most emphasis was laid on the case of change from 'elder brother' to 'son' in the Western Desert (and quite probably in a number of other regions of Australia). ${ }^{16}$ Here it is necessary to explore in more depth what the notion of synchronic variation between kinship terms and 'overlays' of different systems mean in terms of pragmatics and the social situation. In this case we need to broaden the idea of altercentricity and examine how filiocentricity (taking children as the pivot or propositus of the term chosen for use) may lead to such change. Another puzzle is why, unlike in the case of change following more standard extension paths, this kind of mechanism of change seems to leave no trace of transitional polysemy, at least as far as has been found so far.

\section{References}

Agha, Asif. 2007. Language and Social Relations. Cambridge: Cambridge University Press.

16 Harold Koch is currently engaged in researching instances of syncretism between adjacent generation kinship terms with a father-child relationship in south-eastern Australia, which are not examples of standard skewing systems but may be more closely related to filiocentricity as described here. 
AustKin. The Austkin Project: A Database of Australian Aboriginal Systems of Social Organization and Kinship. Online: www.austkin.net (accessed 16 June 2017).

Bowern, Claire, Bethwyn Evans and Louisa Miceli (eds). 2008. Morphology and Language History: In Honour of Harold Koch. Amsterdam: Benjamins. doi.org/10.1075/cilt.298

Dixon, R.M.W. 1981. 'Wargamay'. In Handbook of Australian Languages, vol. 2, edited by R.M.W. Dixon and Barry J. Blake, 1-144. Canberra: ANU Press. doi.org/10.1075/z.hal2.06dix

Dixon, R.M.W. and Barry J. Blake (eds). 1981. Handbook of Australian Languages, vol. 2. Canberra: ANU Press. doi.org/10.1075/z.hal2

Dole, Gertrude. 1969. 'Generation kinship nomenclature as an adaptation to endogamy'. Southwestern Journal of Anthropology. 25(2): 105-23. doi.org/10.1086/soutjanth.25.2.3629197

Dousset, Laurent. 2003. 'On the misinterpretation of the Aluridja kinship system type (Australian Western Desert)'. Social Anthropology 11(1): 43-61. doi.org/10.1111/j.1469-8676.2003.tb00071.x

Dousset, Laurent, Rachel Hendery, Claire Bowern, Harold Koch, Patrick McConvell. 2010. 'Developing a database for Australian Indigenous kinship terminology: The AustKin project'. Australian Aboriginal Studies 1(1): 42-56.

Dyen, Isidore and David Aberle. 1974. Lexical Reconstruction: The Case of the Proto-Athapaskan Kinship System. London and New York: Cambridge University Press.

Evans, Nicholas and David Wilkins. 2001. 'The complete person: Networking the physical and the social'. In Forty Years on: Ken Hale and Australian Languages, edited by Jane Simpson, David G. Nash, Mary Laughren and Barry Alpher, 493-521. Canberra: Pacific Linguistics.

Fison, Lorimer. 1892. 'Address by the President to Section G Anthropology', Report of the Australasian Association for the Advancement of Science, 144-53. Hobart.

Fison, Lorimer and Alfred William Howitt. 1880. Kamilaroi and Kurnai: Group Marriage and Relationship and Marriage by Elopement. Melbourne: George Robertson. 
Garde, Murray. 2013. Culture, Interaction and Person Reference in an Australian Language. Amsterdam: John Benjamins. doi.org/10.1075/ clu. 11

Gardner, Helen and Patrick McConvell. 2015. Southern Anthropology: A History of Fison and Howitt's Kamilaroi and Kurnai. London: Palgrave MacMillan. doi.org/10.1057/9781137463814

Godelier, Maurice, Thomas R. Trautmann and Franklin Edmund Tjon Sie Fat (eds). 1998. Transformations of Kinship. Washington: Smithsonian Institution Press.

Goodenough, Ward (ed.). 1964. Explorations in Cultural Anthropology. New York: McGraw-Hill.

Hansen K.C. and L.E. Hansen. 1992. Pintupi/Luritja Dictionary. Alice Springs: Institute for Aboriginal Development.

Heath, Jeffrey. 2006. 'Kinship expressions and terms'. In Encyclopedia of Languages and Linguistics, 214-16. Amsterdam: Elsevier. doi.org/ 10.1016/B0-08-044854-2/03026-1

Heath, Jeffrey, Francesca Merlan and Alan Rumsey (eds). 1982. Languages of Kinship in Aboriginal Australia. Oceania Monograph 24. Sydney: Oceania.

Holmer, Nils. 1983. Linguistic Survey of South-East Queensland. Canberra: Pacific Linguistics.

Ives, John. 1998. 'Developmental processes in the pre-contact history of Athapaskan, Algonquian and Numic Kin systems'. In Transformations of Kinship, edited by Maurice Godelier, Thomas R. Trautmann and Franklin Edmund Tjon Sie Fat, 94-139. Washington: Smithsonian Institution Press.

Jones, Doug and Bojka Milicic (eds). 2011. Kinship, Language and Prehistory: Per Hage and the Renaissance in Kinship Studies. Salt Lake City: University of Utah Press.

Kronenfeld, David B. 1970. 'The relationship between kinship categories and behavior among the Fanti', PhD dissertation, Stanford University, Ann Arbor: UMI. 
1996. Plastic Glasses and Church Fathers : Semantic Extension From the Ethnoscience Tradition. Oxford Studies in Anthropological Linguistics. New York: Oxford University Press.

- 2009. Fanti Kinship and the Analysis ff Kinship Terminologies. Champaigne, IL: University of Illinois Press.

——. 2013. 'Kinship terms: typology and history'. In Kinship Systems: Change and Reconstruction, edited by Patrick McConvell, Ian Keen and Rachel Hendery, 19-42. Salt Lake City: University of Utah Press.

Laughren, Mary. 1982. 'Warlpiri kinship structure'. In Languages of Kinship in Aboriginal Australia, edited by Jeffrey Heath, Francesca Merlan and Alan Rumsey, 72-85. Oceania Monograph 24. Sydney: Oceania.

Lounsbury, Floyd. 1964. 'A formal account of the Crow- and Omahatype kinship terminologies'. In Explorations in Cultural Anthropology, edited by Ward Goodenough, 351-93. New York: McGraw-Hill.

Mailhammer, Robert (ed.). 2013. Beyond Word Histories: Lexical and Structural Etymology. Berlin: De Gruyter. doi.org/10.1515/ 9781614510581

Malinowski, Bronisław. 1929. The Sexual Life of Savages in North-Western Melanesia: An Ethnographic Account of Courtship, Marriage, and Family Life among the Natives of the Trobriand Islands, British New Guinea. London: Routledge.

McConvell, Patrick. 1997. "The semantic shift between "fish" and "meat" and the prehistory of Pama-Nyungan'. In Boundary Rider: Essays in Honour of Geoffrey O'Grady, edited by Darrell Tryon and Michael Walsh, 303-25. Canberra: Pacific Linguistics.

—_. 2008. 'Grandaddy morphs: The importance of suffixes in reconstructing Pama-Nyungan kinship'. In Morphology and Language History: In Honour of Harold Koch, edited by Claire Bowern, Bethwyn Evans and Louisa Miceli, 313-28. Amsterdam: Benjamins. doi.org/ $10.1075 /$ cilt. $298.27 \mathrm{mcc}$ 
—. 2013a. 'Proto-Pama-Nyungan kinship and the AustKin project: Reconstructing proto-terms for "mother's father" and their transformations'. In Kinship Systems: Change and Reconstruction, edited by Patrick McConvell, Ian Keen and Rachel Hendery, 192-216. Salt Lake City: University of Utah Press.

- 2013b. 'Omaha skewing in Australia: Overlays, dynamism and change'. In Crow-Omaha: New Light on a Classic Problem of Kinship Analysis, edited by Thomas R. Trautmann and Peter M. Whiteley, 243-60. Tucson: University of Arizona Press.

. 2013c. 'Granny got cross: Semantic change of kami in PamaNyungan from "mother's mother" to "father's mother". In Beyond Word Histories: Lexical and Structural Etymology, edited by Robert Mailhammer, 147-84. Berlin: De Gruyter. doi.org/10.1515/ 9781614510581.147

—. 2015. 'Long-distance diffusion of affinal kinship terms as evidence of late holocene change in marriage systems in Aboriginal Australia'. In Strings of Connectedness: Essays in Honour of Ian Keen, edited by Peter Toner, 287-316. Canberra: ANU Press. Online: press-files.anu.edu.au/ downloads/press/p325141/pdf/ch131.pdf (accessed 14 July 2017).

McConvell, Patrick and Barry Alpher. 2003. 'The Omaha trail in Australia: Tracking skewing from east to west'. In Kinship Change, edited by Patrick McConvell, Laurent Dousset and Fiona Powell. Special issue of Anthropological Forum 12(2): 159-75. doi.org/10.1080/ 006646702320622789

McConvell, Patrick and Laurent Dousset. 2012. 'Tracking the dynamics of kinship and social category terms with AustKin II'. Proceedings of the EACL 2012 Joint Workshop of LINGVIS and UNCLH, 98-107. Avignon, France, 23-24 April.

McConvell, Patrick and Ian Keen. 2011. 'The transition from Kariera to an asymmetrical system: Cape York Peninsula to North-east Arnhem Land'. In Kinship, Language and Prehistory: Per Hage and the Renaissance in Kinship Studies, edited by Doug Jones and Bojka Milicic, 99-132. Salt Lake City: University of Utah Press. 
McConvell, Patrick, Ian Keen and Rachel Hendery (eds). 2013. Kinship Systems: Change and Reconstruction. Salt Lake City: University of Utah Press.

Merlan, Francesca. 1982. "Egocentric" and "altercentric" usage of kin terms in Mangarayi'. In Languages of Kinship in Aboriginal Australia, edited by Jeffrey Heath, Francesca Merlan and Alan Rumsey, 128-40 Oceania Monograph 24. Sydney: Oceania.

_- 1989. 'Jawoyn relationship terms: Interactional dimensions of Australian kin classification.' Anthropological Linguistics 31(3-4): 227-63.

Morelli, Steve. 2008. A Gumbaynggir Language Dictionary. 2nd edition. Nambucca Heads, NSW: Muurrbay Aboriginal Language and Culture Co-operative.

Morgan, Lewis Henry. 1871. Systems of Consanguinity and Affinity in the Human Family. Washington DC: Smithsonian Institute.

Murdock, George P. 1949. Social Structure. New York: Macmillan.

Pericliev, Vladimir. 2013. Componential Analysis of Kinship Terminology: a Computational Approach. Basingstoke: Palgrave MacMillan. doi.org/ $10.1057 / 9781137031181$

Radcliffe-Brown, A.R. 1930. 'The social organization of Australian tribes'. Oceania 1(2): 206-46. doi.org/10.1002/j.1834-4461.1930.tb01645.x

Scheffler, Harold W. 1978. Australian Kin Classification. Cambridge Studies in Social Anthropology No. 23. Cambridge: Cambridge University Press. doi.org/10.1017/CBO9780511557590

Simpson, Jane, David G. Nash, Mary Laughren and Barry Alpher (eds). 2001. Forty Years on: Ken Hale and Australian Languages. Canberra: Pacific Linguistics.

Toner, Peter (ed.). 2015. Strings of Connectedness: Essays in Honour of Ian Keen. Canberra: ANU Press. doi.org/10.22459/SC.09.2015.

Trautmann, Thomas R. and Peter M. Whiteley (eds). 2013. Crow-Omaha: New Light on a Classic Problem of Kinship Analysis. Tucson: University of Arizona Press. 
Tryon, Darrell and Michael Walsh (eds). 1997. Boundary Rider: Essays in Honour of Geoffrey O'Grady. Canberra: Pacific Linguistics.

Whistler, Kenneth. 1980. 'Proto-Wintun Kin Classification: A Case Study in Reconstruction of a Complex Semantic System'. PhD dissertation. University of California, Berkeley.

Williams, Gary, Dallas Walker and Steve Morelli. 2014. 'Different talk for different relatives: Relationships shown in restored stories from three Gumbaynggirr (N. Coast NSW) dialects.' Presentation at AIATSIS National Indigenous Studies Conference, Canberra. 28 March. 
This text is taken from Focality and Extension in Kinship: Essays in Memory of Harold W. Scheffler, edited by Warren Shapiro, published 2018 by ANU Press, The Australian National University, Canberra, Australia.

doi.org/10.22459/FEK.04.2018.07 